\title{
High-Frequency Shoot Regeneration From Flower Bud Derived Callus of Gymnostachyum Febrifugum Benth., an Endemic Medicinal Plant to the Western Ghats
}

\section{Silpa P}

Central University of Kerala

Dennis Thuruthiyil Thomas ( $\nabla$ den_thuruthiyil@yahoo.com )

Central University of Kerala https://orcid.org/0000-0001-9283-5723

Original Article

Keywords: Callus, Endemic plant, Flower bud, Gymnostachyum febrifugum, Organogenesis

Posted Date: February 1st, 2021

DOI: https://doi.org/10.21203/rs.3.rs-162342/v1

License: (c) (i) This work is licensed under a Creative Commons Attribution 4.0 International License.

Read Full License 


\section{Abstract}

Gymnostachyum febrifugum Benth. is a small, scapigerous, rare and endemic medicinal herb indigenous to India belonging to the family Acanthaceae. This study reports an efficient protocol for high-frequency flower bud derived callus induction and shoot organogenesis in $G$. febrifugum. Flower buds at $7 \mathrm{~d}$ before anthesis (dBA) were excised from the inflorescence and cultured on MS medium supplemented with various concentrations of 2, 4-dichlorophenoxy acetic acid (2, 4-D; 0.5-2.0 mg/l) for callus induction. The optimum callus induction (78\%) was obtained on MS medium supplemented with $1.5 \mathrm{mg} / \mathrm{l} 2,4-\mathrm{D}$. The calli when subcultured on MS medium supplemented with different concentrations of thidiazuron (TDZ; 0.5-2.5 mg/l) or 6-benzylaminopurine BAP $(0.5-2.5 \mathrm{mg} / \mathrm{l})$ alone or in combination with 1naphthaleneacetic acid (NAA; 0.2-0.7 mg/l) induced shoots. The highest frequency (94\%) and number of shoots (44.6 shoots/unit callus) were obtained on MS medium supplemented with $2.0 \mathrm{mg} / \mathrm{I} \mathrm{TDZ}$ and 0.5 mg/l NAA. The optimum rooting frequency (95\%) and number of roots (10.2) were observed on $1 / 2 \mathrm{MS}$ medium supplemented with $3.0 \mathrm{mg} / \mathrm{l}$ indole-3- butyric acid (IBA). The rooted plantlets were acclimatized and transferred to soil with $94 \%$ success.

\section{Introduction}

Gymnostachyum febrifugum Benth. is a rare endemic plant belonging to the family Acanthaceae (Thomas et al. 1996). This is a pretty, stemless, tiny and scapigerous herb with large long-petiolated ovate leaves and woody rootstock (Fig. 1; Gamble 1924). This plant is indigenous to India and is having a very beautiful attractive flower, which makes it a potential wild ornamental plant (Thomas et al. 1996). Inflorescence in $G$. febrifugum is a spike with limited flowered cymes and the flower is white tinged with purple colour and the lower lip appear yellow. The root of this plant is used as febrifuge and against blisters and sores on the tongue (Pattanayak 2019).

According to Mascarenhas (2010) the threat status of this plant is near threatened. Hence, there is an urgent need for the conservation of this plant. Conventional propagation of this plant is through seeds and our study revealed that the seed formation in fruits is comparatively low probably due to selfincompatibility. Additionally, low viability and formation of a high percentage of sterile seeds are the difficulties associated with its propagation. Further, vegetative propagation is not very promising due to the lack of erect stem in $G$. febrifugum. In this background, micropropagation is considered as a viable option to rapidly propagate this plant (Ramírez-Mosqueda and Iglesias-Andreu 2016).

Since this plant is devoid of an erect stem, the collection of explants like leaf and subterranean parts often cause high rate of contamination. The flower bud is considered as an ideal explant for micropropagation of this plant since it can reduce contamination rate substantially and also avoid destroying the mother plant by collecting other explants.

Although plant tissue culture related instability in regenerating plants is prevalent in several systems, somaclonal variation is considered as an additional tool for the improvement of agricultural as well as 
horticultural crops along with well-established plant breeding methods (Arun et al. 2003; Santha and Mehta 2001; Anil et al. 2018). The cause of such variations is basically due to various reasons such as genetic, phenotypic and epigenetic alterations observed in plants growing in cultures (Karp 1995). Such variations may increase if the pathway is through callus organogenesis. Other factors which determine the variations include the medium and maintenance time in culture. The somaclonal variants usually appear due to the structural and numerical changes in chromosomes (Bairu et al. 2011; Delgado-Paredes et al. 2017).

The use of plant tissue culture techniques has been considerably increased over the past few decades for the mass propagation of rare, endangered, endemic and threatened plants (for review see Deepa and Thomas 2020). Micropropagation technique can give rise to large number of plants in a very limited period irrespective of season and climate (Liao et al. 2011). This technique is more effective in producing mass scale elite, healthy, disease-free plants as compared to that of conventional propagation protocols (Vieitez et al. 2007; Corredoira et al., 2017). Further, this technique can support the improvement of agriculture, horticulture and forestry plants. Various approaches like nodal segment culture, adventitious shoot formation, direct and indirect organogenesis and somatic embryogenesis are frequently used for the multiplication of various plant species (Demétrio et al. 2021; Kannan et al. 2021; Saavedra et al. 2021; Patel et al. 2021). To our knowledge, there is no report on in vitro propagation of $G$. febrifugum. Therefore, in this study, we report an efficient high frequency shoot induction protocol from flower bud derived callus.

\section{Materials And Methods}

\section{Plant material and surface sterilization}

G. febrifugum flowers from July to November. The plant bears beautiful flowers during this period. The flowers are arranged in a cymose inflorescence. Flower buds were collected from such inflorescences. For our study, we have selected flower buds at three different stages of development i.e. 4, 7, 10d before anthesis (dBA). The flower buds were excised from the inflorescence of field-grown plants and brought to the lab in the morning. The flower buds were excised and collected. Each flower bud has a small stalk at the cut end. The flower buds were washed thoroughly in sterilized distilled water for 5 min and then immersed in sterilized distilled water containing 1\% Savlon solution for $8 \mathrm{~min}$. followed by two rinses in sterilized distilled water. Finally, the explants were surface sterilized with $0.1 \%$ mercuric chloride $\left(\mathrm{HgCl}_{2}\right)$ for $7 \mathrm{~min}$. The explants were then washed three times with sterilized distilled water. The buds were then kept in sterilized glass Petri plates lined with blotting paper to remove traces of water.

Media and culture initiation

MS medium was invariably used throughout the experiment and is supplemented with various plant growth regulators. The $\mathrm{pH}$ of the medium was adjusted to 5.8 by using $0.1 \mathrm{~N} \mathrm{NaOH}$ or $0.1 \mathrm{~N} \mathrm{HCl}$ before gelling with $8.0 \mathrm{~g} / \mathrm{l}$ bacteriological agar (Himedia, India). For callus induction from flower buds, different 
concentrations of 2, 4-D ( 0.5 to $2.0 \mathrm{mg} / \mathrm{l})$ was employed. The flower buds were horizontally placed in Petri plates and the basal stock portion of the flower buds was slightly pushed in the medium at the time of inoculation. The calli induced from explants were subcultured on MS medium supplemented with 0.5 $\mathrm{mg} / \mathrm{l}$ 2, 4-D for multiplication in every 4 weeks.

For shoot regeneration from callus

The callus was subcultured on MS medium augmented with various concentrations of TDZ (0.5-2.5 $\mathrm{mg} / \mathrm{l})$ or BAP $(0.5-2.5 \mathrm{mg} / \mathrm{l})$ alone and in combination with NAA $(0.2-0.7 \mathrm{mg} / \mathrm{l})$ for shoot induction. For shoot induction, $1.0 \mathrm{~g}$ callus was inoculated in each container. The per cent response, number of shoots and mean shoot length were measured $45 \mathrm{~d}$ after culture.

Culture conditions and Statistical analysis

The cultures were incubated at $22 \pm 2^{\circ} \mathrm{C}$, in the culture room with 16 -h light conditions and $40-50 \mu \mathrm{mol}$ $\mathrm{m}^{2} / \mathrm{s}$ photosynthetic photon flux (PPF) provided by white, cool fluorescent lamps. For each experiment, at least 14 replicates were taken and each experiment was repeated three times. Statistical analysis was performed by using analysis of variance (ANOVA) through SPSS software. Data were analysed for the significance of differences of means among treatments using Duncan's multiple range test (DMRT) at $P$ $\leq 0.05$.

\section{Results And Discussion}

Callus induction from flower buds

Our primary aim was to standardize the suitable stage of the flower bud and 2, 4-D concentration for optimum callus induction. The flower buds 4,7 and $10 \mathrm{dBA}$ were excised from the inflorescence in the morning hours and brought to the lab for inoculation (Fig. 2A-C). The flower buds were then subjected to four different callus induction treatments, which include MS medium supplemented with $0.5,1.0,1.5$ and $2.0 \mathrm{mg} / \mathrm{l}$ 2, 4-D (Table 1). In almost all concentrations of 2, 4-D tested, calli induced with similar textures whereas on basal medium (control) there was no callus induction. Callus initiation started 2 weeks after culture (Fig. 2D). Initially, the calli appeared as small granules on the surface of the explant and later it slowly spread to the entire surface and after 6 weeks the calli completely covered the explants in responding cultures (Fig. 2E). Due to the presence of anthocyanin pigments in the explant, the calli showed pink spots occasionally (Fig. 2F, G). 
Table 1

Effect of age of flower buds (4, 7 and 10-d before anthesis) and various concentrations of 2, 4-D on callus induction from flower bud explants of $G$. febrifugum after 6 weeks of culture. Minimum 24 explants were cultured in each treatment and all the experiments were repeated 3 times.

\begin{tabular}{|c|c|c|c|c|c|c|}
\hline \multirow{2}{*}{$\begin{array}{l}2,4-D \\
(\mathrm{mg} / \mathrm{l})\end{array}$} & \multicolumn{2}{|l|}{ 4-d-BA } & \multicolumn{2}{|l|}{ 7-d-BA } & \multicolumn{2}{|l|}{ 10-d-BA } \\
\hline & $\begin{array}{l}\text { Explants with } \\
\text { calli }^{\mathrm{a}}(\%)\end{array}$ & $\begin{array}{l}\text { Size of } \\
\text { calli }\end{array}$ & $\begin{array}{l}\text { Explants with } \\
\text { calli (\%) }\end{array}$ & $\begin{array}{l}\text { Size of } \\
\text { calli }\end{array}$ & $\begin{array}{l}\text { Explants with } \\
\text { calli }(\%)^{\mathrm{a}}\end{array}$ & $\begin{array}{l}\text { Size of } \\
\text { calli }\end{array}$ \\
\hline 0.0 & 0.0 & 0.0 & 0.0 & 0.0 & 0.0 & 0.0 \\
\hline 0.5 & $13 \pm 1.3 b$ & * & $27 \pm 2.3 c$ & * & - & - \\
\hline 1.0 & $28 \pm 2.9 \mathrm{a}$ & * & $62 \pm 2.1 b$ & 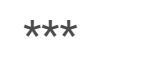 & $10 \pm 1.2 b$ & * \\
\hline 1.5 & $31 \pm 2.3 a$ & $\star \star$ & $78 \pm 1.9 a$ & $\star \star \star$ & $23 \pm 1.7 a$ & ** \\
\hline 2.0 & $20 \pm 2.8 a b$ & * & $56 \pm 2.8 b$ & ** & $27 \pm 1.9 a$ & * \\
\hline \multicolumn{7}{|c|}{ Callus size: ${ }^{*}$ - small, $* *$ - medium, $\star * *$ - large } \\
\hline
\end{tabular}

Table 1 depicts callus induction using flower buds at 4, 7 and $10 \mathrm{dBA}$ on MS medium supplemented with 0.5, 1.0, 1.5 and $2.0 \mathrm{mg} / \mathrm{l}$ 2, 4-D 45d after culture. There was no callus induction on MS basal medium. The per cent explants with calli and callus size were influenced by the age of the flower bud as well as concentration of 2, 4-D. Flower buds collected 4 dBA showed small to medium size calli in 13 to $31 \%$ explants on various concentrations of 2, 4-D (Table 1). When flower buds collected $10 \mathrm{dBA}$ were cultured on $0.5 \mathrm{mg} / \mathrm{I} 2$, 4-D, there was no callus initiation. However, on other 2, 4-D concentrations it exhibited small to medium size calli in 10 to $27 \%$ explants. The flower buds collected $7 \mathrm{dBA}$ when cultured on 1.5 $\mathrm{mg} / \mathrm{l} 2$, 4-D exhibited the optimum response of $78 \%$ explants with large size calli (Table 1). This calli also had the highest biomass i.e. $2.6 \pm 1.2 \mathrm{~g}$ fresh weight per callus mass. On this medium, the earliest callus induction was noticed (7-9d) and flower buds from $4 \mathrm{dBA}$ and $10 \mathrm{dBA}$ took longer to induce callus (1214d). All the calli induced were of friable texture. Since the highest callus induction frequency and callus size was observed on $1.5 \mathrm{mg} / \mathrm{l}$ 2, 4-D in flower buds collected $7 \mathrm{dBA}$, all further callus induction experiments were done with this explant and media combination. The age of the flower bud is an important factor, which influences the callus induction and subsequent shoot organogenesis in some systems. In Gerbera jamesonii 7, 8, 9, 10 and 11-d-old flower buds were cultured to induce callus. In all four varieties, 7-9-d-old flower buds showed the best response in terms of both callus induction as well as shoot organogenesis (Akter et al. 2012). The auxin 2, 4- D is routinely used for callus induction from various explants in different systems (Rathore et al. 2011; Abraham and Thomas 2015; Bala et al. 2015; Patricia 2021). According to Zheng and Konzak (1999) 2, 4-D induced highest callus induction could be achieved not only by the use of proper concentration but also its duration of presence in the medium. 
The calli during its initiation stage remained predominantly pinkish in colour whereas later as the calli grow further, it turned in to light yellow and green (Fig. 2D-G). However, pinkish spots were regularly noticed on all calli during the entire period of culture. This pinkish colour is due to the exudation of the flavonoid compound anthocyanins present in the explant. The presence of anthocyanins was reported in various parts of some plants especially in flowers, fruits and vegetables (Mihai et al. 2010). The induced calli were subcultured on MS medium supplemented with $0.5 \mathrm{mg} / \mathrm{l}$ 2, 4-D for multiplication after $45 \mathrm{~d}$.

Shoot regeneration from callus

Well-developed friable yellowish-white calli with pink spots were subcultured on MS medium supplemented with TDZ (0.5 to $2.5 \mathrm{mg} / \mathrm{l}$ ) or BA (0.5 to $2.5 \mathrm{mg} / \mathrm{l}$ ) alone or in combination with NAA (0.2$0.7 \mathrm{mg} / \mathrm{l})$ for shoot induction (Table 2). The calli were inoculated (2.0 gm fresh weight per bottle) in culture bottles containing $150 \mathrm{ml}$ medium. The data for per cent cultures responding, number of shoots and mean shoot length were recorded $45 \mathrm{~d}$ after culture. In this study, two cytokinins were used for shoot organogenesis from callus i. e. BAP and TDZ. Comparatively, TDZ showed better response than BAP. BAP at $1.5 \mathrm{mg} / \mathrm{I}$ produced an optimum $56 \%$ response with 15.4 shoots per unit calli. The calli showed maximum percentage response (68) and number of shoots (22.5) on MS medium supplemented with 2.0 $\mathrm{mg} / \mathrm{I} \mathrm{TDZ}$ when used individually. However, the addition of an auxin NAA significantly improved the percentage response and number of shoots. BAP at $1.5 \mathrm{mg} / \mathrm{l}$ in combination with $0.2 \mathrm{mg} / \mathrm{l} \mathrm{NAA}$ produced optimum $67 \%$ response. However, the shoot number was optimum (28.4) on $0.5 \mathrm{mg} / \mathrm{l} \mathrm{NAA}$ in combination with $1.0 \mathrm{mg} / \mathrm{I}$ BAP. The highest per cent shoot induction and number of shoots was observed on MS medium supplemented with $2.0 \mathrm{mg} / \mathrm{I} \mathrm{TDZ}$ and $0.5 \mathrm{mg} / \mathrm{I} \mathrm{NAA}$. On this medium $94 \%$ cultures produced shoots from callus with a mean number of 44.6 after $45 \mathrm{~d}$ of culture (Table 2 ). Although the per cent response and number of shoots varied depending on the type of plant growth regulators and concentrations, there was not much difference in mean shoot length. Some regions of the calli turned green after 2 weeks of culture and the shoot initiation started from such regions (Fig. 2F, G). Later the shoots were formed all over the surface of the calli (Fig. 3A). 
Table 2

Effect of various concentrations of TDZ or BAP alone or in combination with NAA on shoot organogenesis from callus.

\begin{tabular}{|c|c|c|c|c|c|}
\hline \multicolumn{3}{|c|}{ PGRs } & \multirow[t]{2}{*}{$\%$ response* } & \multirow[t]{2}{*}{ No of shoots* } & \multirow[t]{2}{*}{ Mean shoot length* } \\
\hline TDZ & BAP & NAA & & & \\
\hline 0.0 & 0.0 & 0.0 & 0.0 & 0.0 & 0.0 \\
\hline 0.5 & & & $45 \pm 6.3 \mathrm{de}$ & $10.4 \pm 1.9 f$ & $1.2 \pm 0.08 a$ \\
\hline 1.0 & & & $58 \pm 7.8 c$ & $14.2 \pm 2.3 e$ & $1.4 \pm 0.09 a$ \\
\hline 1.5 & & & $60 \pm 4.2 c$ & $19.2 \pm 2.2 \mathrm{~d}$ & $1.2 \pm 0.06 a$ \\
\hline 2.0 & & & $68 \pm 5.1 c$ & $22.5 \pm 2.5 \mathrm{~cd}$ & $1.0 \pm 0.08 a$ \\
\hline 2.5 & & & $55 \pm 6.6 d$ & $14.7 \pm 2.1 \mathrm{e}$ & $1.2 \pm 0.05 a$ \\
\hline & 0.5 & & $42 \pm 7.9 e$ & $9.6 \pm 1.9 f$ & $0.7 \pm 0.05 a$ \\
\hline & 1.0 & & $49 \pm 6.2 \mathrm{de}$ & $12.4 \pm 1.6 \mathrm{ef}$ & $0.9 \pm 0.08 a$ \\
\hline & 1.5 & & $56 \pm 6.6 d$ & $15.4 \pm 1.8 d$ & $1.2 \pm 0.09 a$ \\
\hline & 2.0 & & $28 \pm 4.2 f$ & $12.8 \pm 1.4 \mathrm{ef}$ & $1.3 \pm 0.07 a$ \\
\hline & 2.5 & & $16 \pm 2.8 \mathrm{~g}$ & $12.5 \pm 2.1 \mathrm{ef}$ & $1.0 \pm 0.05 a$ \\
\hline 2.0 & & 0.2 & $79 \pm 9.7 b$ & $31.5 \pm 2.2 b$ & $1.2 \pm 0.09 a$ \\
\hline 2.0 & & 0.5 & $94 \pm 8.4 a$ & $44.6 \pm 2.8 \mathrm{a}$ & $1.0 \pm 0.06 a$ \\
\hline 2.0 & & 0.7 & $76 \pm 9.8 b$ & $31.3 \pm 2.9 b$ & $1.2 \pm 0.07 a$ \\
\hline & 1.5 & 0.2 & $67 \pm 8.5 c$ & $22.9 \pm 2.6 \mathrm{~cd}$ & $1.0 \pm 0.05 a$ \\
\hline & 1.5 & 0.5 & $55 \pm 9.1 d$ & $28.4 \pm 2.8 \mathrm{bc}$ & $1.1 \pm 0.04 a$ \\
\hline & 1.5 & 0.7 & $51 \pm 8.7 d$ & $25.3 \pm 2.5 c$ & $1.2 \pm 0.08 a$ \\
\hline
\end{tabular}


Table 2

Efficiency of rooting in G. febrifugum on $1 / 2$ MS medium supplemented with various concentrations of IBA after $45 \mathrm{~d}$ of culture.

\begin{tabular}{|llll|}
\hline IBA $(\mathrm{mg} / \mathrm{l})$ & \% response* & Mean number of roots* & Mean root length* \\
\hline 0.0 & 0.0 & 0.0 & 0.0 \\
\hline 1.0 & $77 \pm 8.6 \mathrm{c}$ & $4.6 \pm 1.6 \mathrm{c}$ & $1.8 \pm 0.6 \mathrm{~b}$ \\
\hline 2.0 & $84 \pm 7.9 \mathrm{~b}$ & $6.8 \pm 1.4 \mathrm{bc}$ & $2.1 \pm 0.9 \mathrm{a}$ \\
\hline 3.0 & $95 \pm 9.6 \mathrm{a}$ & $10.2 \pm 1.9 \mathrm{a}$ & $2.6 \pm 0.8 \mathrm{a}$ \\
\hline 4.0 & $81 \pm 8.4 \mathrm{bc}$ & $8.4 \pm 1.8 \mathrm{~b}$ & $1.4 \pm 0.7 \mathrm{~b}$ \\
\hline * Values represent mean \pm SE. Means followed by same letter are not significantly different $(\mathrm{p} \leq 0.05)$ \\
\hline
\end{tabular}

In the present study, a combination of TDZ and NAA produced the highest shoot induction from callus. The synergistic action of TDZ and auxin-induced shoot induction has been reported in several systems including Solanum khasianum (Chirumamilla 2021), Ficus carica (Abdolinejad 2020) and Dieffenbachia (Shen 2008). TDZ is an active cytokinin extensively used for shoot induction from various explants in different systems (Deepa et al. 2018). TDZ was found more efficient than other cytokinins in some systems (Zhang et al. 2011; (Bhattacharyya et al. 2016). TDZ stimulated shoot organogenesis from various systems including medicinal plants, trees and endangered plants were reported by many workers (for review see Deepa et al. 2018).

In the present study, we used flower bud as explant. There are various reports in which young tissues like flower buds and inflorescence segments were used as explants for shoot induction. In Arnebia hispidissima of the various explants like leaf, immature inflorescence and mature and immature seeds, employed for callus induction and shoot regeneration, only immature inflorescence responded (Phulwaria and Shekhawat 2013). Flower buds were used for micropropagation in some systems (Akter et al. 2012; Liao et al. 2011; Yang et al. 2011). Young tissues like immature inflorescence, flower buds etc have high meristematic activity and form excellent material for micropropagation studies (Kackar and Shekhawat 1991; Yadav et al. 2009; Głowacka et al. 2010). There are some reports, which suggest that floral structures have more ability to reproduce vegetatively than other plant parts (Gingas 1991; Lopez-Baez et al. 1993; Merkle et al. 1997; Steinmacher et al. 2007).

Rooting of shoots

For root induction, micropropagated shoots measuring a size of about $1.0 \mathrm{~cm}$ or above were used. The shoots were cultured on $1 / 2 \mathrm{MS}$ medium supplemented with various concentrations of IBA (1.0-4.0 mg/l). On MS basal medium (control) there was no root induction. Half strength MS medium supplemented with $3.0 \mathrm{mg} / \mathrm{I} \mathrm{IBA}$ possessed the highest frequency of root induction (95\%) and number of roots per explant (10.2) as well as mean root length $(2.6 \mathrm{~cm})$. IBA induced root induction has been reported in other 
systems like Plumbago zeylanica (Sharma and Agarwal 2018), Pterocarpus marsupium (Ahmad et al. 2021) and Swertia minor (Kshirsagar et al. 2021)

In conclusion, a robust shoot regeneration system through flower bud derived callus organogenesis has been standardized for $G$. febrifugum. This protocol could be utilized for the mass multiplication of this plant for commercial purpose.

\section{Declarations}

\section{Acknowledgements}

Silpa P thankfully acknowledges the financial support from CSIR, Govt. of India in the form of JRF and SRF.

\section{Author contributions}

SP performed tissue culture experiments, analyzed data, wrote the manuscript. TDT designed the experiment, contributed to writing and corrected manuscript.

\section{Compliance with ethical standards}

\section{Ethics approval}

This research paper does not contain any studies with human participants or animals performed by any of the authors.

\section{Consent to participate}

Informed consent was obtained from all individual participants included in the study.

\section{Consent for publication}

Not applicable

\section{Conflict of interest}

The authors declare that they have no conflicts of interest.

\section{References}

Abdolinejad R, Shekafandeh A, Jowkar A, Gharaghani A Alemzadeh A (2020) Indirect regeneration of Ficus carica by the TCL technique and genetic fidelity evaluation of the regenerated plants using flow cytometry and ISSR. Plant Cell Tissue Organ Cult 143:131-144 
Abraham J, Thomas TD (2015) Plant regeneration from organogenic callus and assessment of clonal fidelity in Elephantopus scaber Linn., an ethnomedicinal herb. Physiol Mol Biol Plants 21:269-277

Ahmad A, Ahmad N, Anis M, Alatar AA, Abdel-Salam EM, Qahtan AA, Faisal M (2021) Gibberellic acid and thidiazuron promote micropropagation of an endangered woody tree (Pterocarpus marsupium Roxb.) using in vitro seedlings. Plant Cell Tissue Organ Cult https://doi.org/10.1007/s11240-020-01969-1

Akter N, Hoque Ml, Sarker RH (2012) In vitro propagation in three varieties of gerbera (Gerbera jamesonii Bolus.) from flower bud and flower stalk explants. Plant tissue cult biotech 22:143-152

Anil VS, Bennur S, Lobo S (2018) Somaclonal variations for crop improvement: selection for disease resistant variants in vitro. Plant Sci Today 5:44-54

Arun B, Joshi AK, Chand R, Singh BD (2003) Wheat somaclonal variants showing earliness, improved spot blotch resistance and higher yield. Euphytica 132:235-241

Bairu MW, Aremu OA, Van-Staden J (2011) Somaclonal variation in plants: causes and detection methods. Plant Growth Regul 63:147-173

Bala R, Beniwal VS, Laura JS (2015) An efficient and reproducible indirect shoot regeneration from female leaf explants of Simmondsia chinensis, a liquid-wax producing shrub. Physiol Mol Biol Plants 21:293-299

Bhattacharyya P, Kumaria S, Job N, Tandon P (2016) En-masse production of elite clones of Dendrobium crepidatum: a threatened, medicinal orchid used in traditional Chinese medicine (TCM). J Appl Res Med Aroma 3:168-176

Chirumamilla P, Gopu C, Jogam P, Taduri S (2021) Highly efficient rapid micropropagation and assessment of genetic fidelity of regenerants by ISSR and SCoT markers of Solanumkhasianum Clarke. Plant Cell Tissue Organ Cult https://doi.org/10.1007/s11240-020-01964-6

Corredoira E, Martinez MT, Cernadas MJ, San Jose MC (2017) Application of biotechnology in the conservation of the genus Castanea. Forests 8:394

Deepa AV, Anju M, Thomas TD (2018) The applications of TDZ in medicinal plant tissue culture. In: Ahmad N, Faisal M (Eds) Thidiazuron: From urea derivative to plant growth regulator. Springer, Singapore, pp 297-316

Deepa AV, Thomas TD (2020) In vitro strategies for the conservation of Indian medicinal climbers. In Vitro Cell Dev Biol - Plant 56:784-802

Delgado-Paredes GE, Consuelo RI, Jorge CC, Eny ISF, Walter H (2017) Development and agronomic evaluation of in vitro somaclonal variation in sweet potato regenerated plants from direct organogenesis of roots. Asian J Plant Sci Res 7:39-48 
Demétrio CA, De Oliveira Jacob JF, Ambrosano GV, De Oliveira ET, Viegas Rodrigues PH (2021) In vitro propagation of cambuci (Campomanesia phaea): An endangered exotic fruit and ornamental plant from Brazilian Atlantic forest. Plant Cell Tissue Organ Cult https://doi.org/10.1007/s11240-020-02002-1

Gamble JS (1924) Flora of the Presidency of Madras, Vol. 2: 1053. Adlard and Son Ltd., London. Rept. 2004. Bishen Singh Mahendra Pal Singh, Debra Dun.

Gingas VM (1991) A sexual embryogenesis and plant regeneration from female catkins of Quercus. Hortscience 26:1217-1218

Głowacka K, Jezowski S, Kaczmarek Z (2010) The effects of genotype, inflorescence developmental stage and induction medium on callus induction and plant regeneration in two Miscanthus species. Plant Cell Tissue Organ Cult 102:79-86

Kackar A, Shekhawat NS (1991) Plant regeneration from cultured immature inflorescence of Cenchrus setigerus and Cenchrus ciliarsi. Ind J Exp Biol 29:62-64

Kannan N, Manokari M, Shekhawat MS (2021) Induction of adventitious roots from leaf explants of Morinda coreia Buch. and ham. : an important dye yielding plant. Plant Cell Tissue Organ Cult https://doi.org/10.1007/s11240-021-02016-3

Karp A (1995) Somaclonal variation as a tool for crop improvement. Euphytica 85:295-302

Kshirsagar PR, Mohite A, Suryawanshi S, Chavan JJ, Gaikwad NB, Bapat VA (2021) Plant regeneration through direct and indirect organogenesis, phyto-molecular profiles, antioxidant properties and swertiamarin production in elicitated cell suspension cultures of Swertia minor (Griseb.) Knobl. Plant Cell Tissue Organ Cult. https://doi.org/10.1007/s11240-020-01962-8

Liao YJ, Tsai YC, Sun YW, Lin RS, Wu FS (2011) In vitro shoot induction and plant regeneration from flower buds in Paphiopedilum orchids. In Vitro Cell Dev Biol - Plant 47:702-709

Lopez-Baez O, Bollon H, Eskes A, Petiard V (1993) Somatic embryogenesis and plant regeneration from flower parts of cocoa Theobroma cacao L. C R Acad Sci Paris 316:579-584

Mascarenhas MEC (2010) Systematic studies on the endemic species of the family Acanthaceae from the Northern and parts of central Western Ghats. Thesis submitted to Goa University, India, pp. 58-61

Merkle SA, Bailey RL, Pauley BA, Neu KA, Kim MK, Rugh CL, Montello PM (1997) Somatic embryogenesis from tissues of mature sweetgum trees. Can J For Res 27:959-964

Mihai R, Mitoi M, Brezeanu A, CoGalniceanu G (2010) Two-stage system, a possible strategy for the enhancement of anthocyanin biosynthesis in a long-term grape callus cultures. Rom Biotechnol Lett 15:5025-5033 
Patel SR, Joshi AG, Pathak AR, Shrivastava N, Sharma S (2021) Somatic embryogenesis in Leptadenia reticulata (Retz.) Wight and Arn along with assessment of shoot and callus cultures for HPTLC fngerprint and quantifcation of p-coumaric acid. Plant Cell Tissue Organ Cult https://doi.org/10.1007/s11240-02002000-3

Pattanayak S (2019) Health care system using succulent parts of plants. Calcutta Block and Print, Sikdar Bagan St, Kolkata, India, p.77

Patricia D, Stephen B, John A (2021) Shoot organogenesis from leaf discs of the African ginger (Mondia whitei (Hook.f.) Skeels), an endangered medicinal plant. In Vitro Cell Dev Biol - Plant https://doi.org/10.1007/s11627-020-10146-0

Phulwaria M, Shekhawat NS (2013) An efficient in vitro shoot regeneration from immature inflorescence and ex vitro rooting of Arnebia hispidissima (Lehm). DC. - A red dye (Alkannin) yielding plant. Physiol Mol Biol Plants 19:435-441

Ramírez-Mosqueda MA, Iglesias-Andreu LG (2016) Evaluation of different temporary immersion systems $(B I T \AA, B I G$ and RITA $\AA$ ) in the micropropagation of Vanilla planifolia Jacks. In Vitro Cell Dev Biol - Plant $52: 154-160$

Rathore MS, Chikara J, Mastan SG, Rahman H, Anand KGV, Shekhawat NS (2011) Assessment of genetic stability and instability of tissue culture-propagated plantlets of Aloe vera L. by RAPD and ISSR markers. Appl Biochem Biotechnol 165:1356-1365

Saavedra AM, De Castro TC, Da Silva Cordeiro L, Athayde T, Albarello N, Simões-Gurgel C (2021) In vitro propagation and cryopreservation of the medicinal species Hovenia dulcis Thunb. (Rhamnaceae). Plant Cell Tissue Organ Cult https://doi.org/10.1007/s11240-020-01980-6

Santha IM, Mehta SL (2001) Development of low ODAP somaclones of Lathyrus sativus. Lathyrus Lathyrism Newslett 2:42

Sharma U, Agrawal V (2018) In vitro shoot regeneration and enhanced synthesis of plumbagin in root callus of Plumbago zeylanica L. -an important medicinal herb. In Vitro Cell Dev Biol - Plant 54:423-435

Shen X, Kane ME, Chen J (2008) Effects of genotype, explant source and plant growth regulators on indirect shoot organogenesis in Dieffenbachia cultivars. In Vitro Cell Dev Biol - Plant 44:282-288

Steinmacher DA, Clement CR, Guerra MP (2007) Somatic embryogenesis from immature peach palm inflorescence explants: towards development of an efficient protocol. Plant Cell Tissue Organ Cult 89:1522

Thomas J, Santhosh Kumar ES, Abdul Jabar M (1996) Gymnostachyum febrifugum var bracteatum: a potential wild ornamental plant. Ind Hortic 4:22 
Vieitez AM, Sänchez MC, García-Nimo ML, Ballester A (2007) Protocol for micropropagation of Castanea Sativa, In: Jain SM, Häggman H (Eds.) Protocols for micropropagation of woody trees and fruits. Springer Netherlands, Dordrecht, pp. 299-312

Yadav CB, Jha P, Mahalakshmi C, Anjaiah V, Bhat V (2009) Somatic embryogenesis and regeneration of Cenchrus ciliaris genotypes from immature inflorescence explants. Biol Plant 53:603-609

Yang JL, Niu YD, Yang CP, Liu GF, Li CH (2011) Induction of somatic embryogenesis from female flower buds of elite Schidandra chinensis. Plant Cell Tissue Organ Cult 106:391-399

Zhang C, Chen D, Elliott MC, Slater A (2011) Thidiazuron induced organogenesis and somatic embryogenesis in sugar beet (Beta vulgaris L.). In Vitro Cell Dev Biol - Plant 37:305-310

Zheng MY, Konzak CF (1999) Effect of 2, 4-D on callus induction and plant regeneration in anther culture of wheat. Plant Cell Rep 19:69-73

\section{Figures}

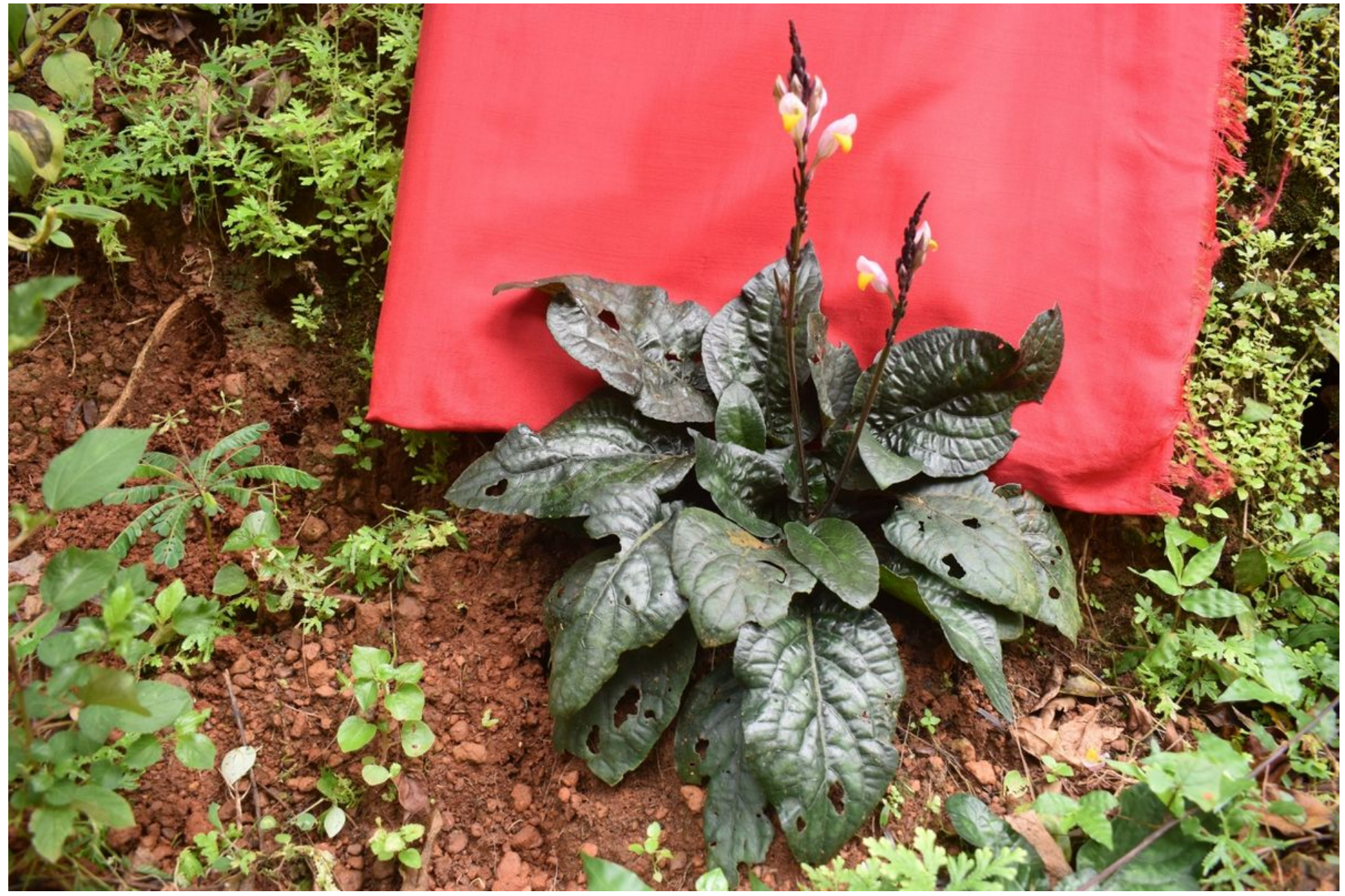

Figure 1 
Habit of G. febrifugum showing the plant and inflorescence.
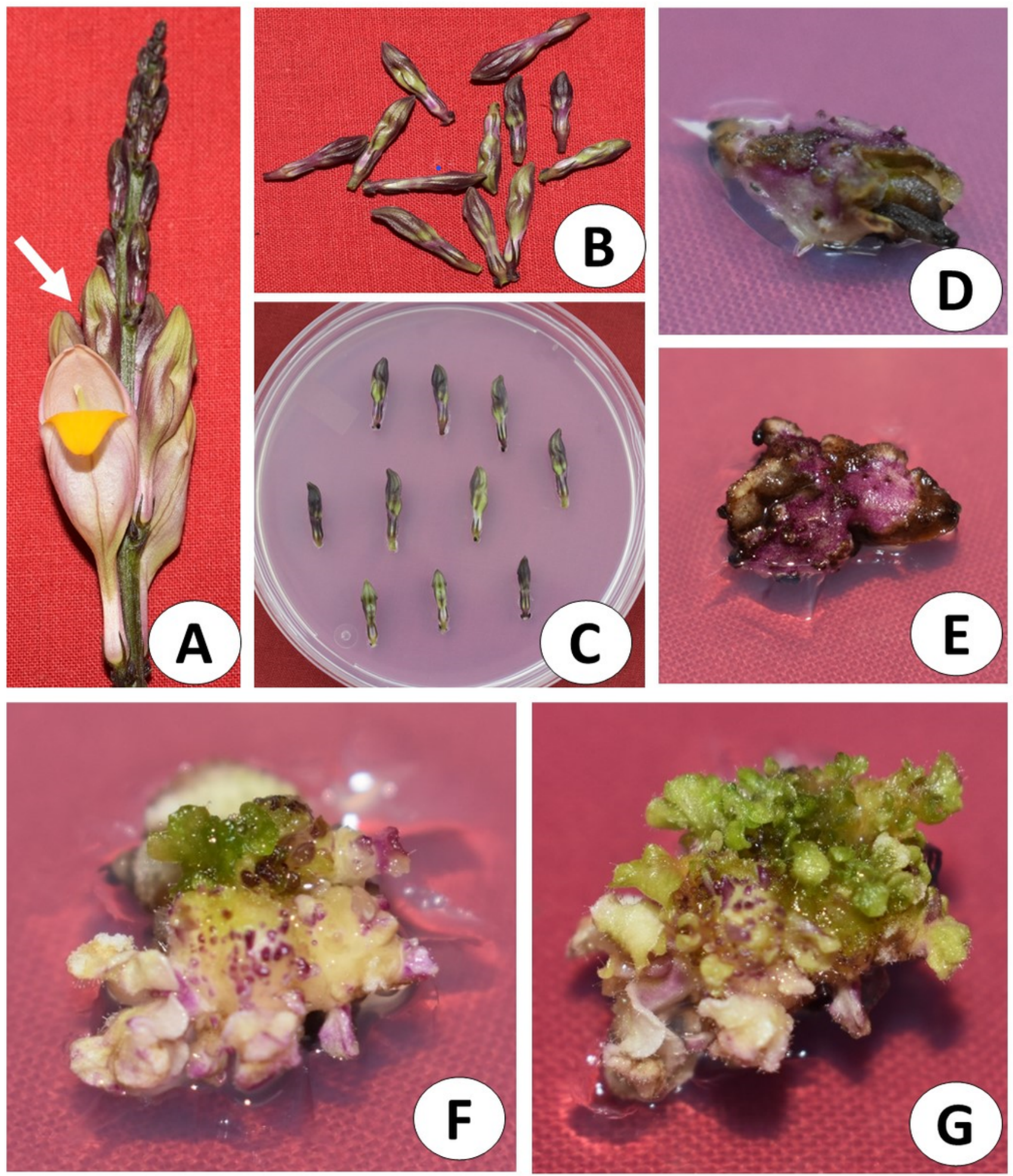

\section{Figure 2}

Callus induction and shoot organogenesis from flower bud derived callus in G. febrifugum. A. A close up view of the inflorescence with flower buds. B. Flower buds $7 \mathrm{dBA}$ just before culture. C. Flower buds at the time of culture in Petri plates. D. Flower bud 2 weeks after culture. Calli started emerging from the surface of the explant. E. Same as in fig. 1D, 3 weeks after culture. Thick layer of calli developed all over the 
surface of the explant. F. Shoot initiation from calli on MS medium supplemented with $2.0 \mathrm{mg} / \mathrm{I} \mathrm{TDZ}$ and $0.5 \mathrm{mg} / \mathrm{I}$ NAA 1 week after culture. Tiny green coloured shoots were emerged from the calli. G. Same as in fig. 1F, 2 weeks after culture. More number of elongated shoots were developed from the calli.
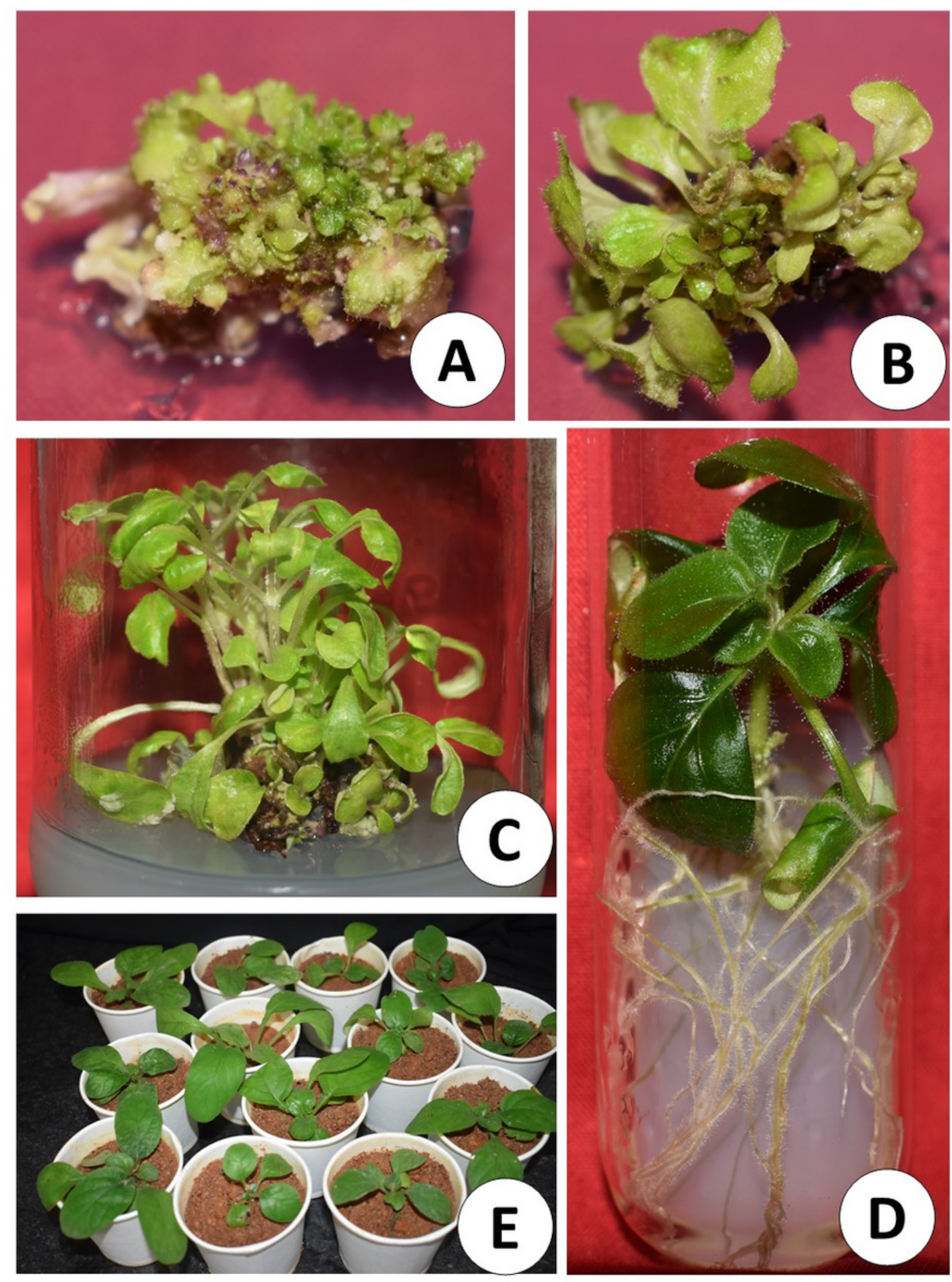

\section{Figure 3}

Shoot organogenesis from callus, rooting and transplantation of G. febrifugum. A. Shoots induced from callus on MS medium supplemented with $2.0 \mathrm{mg} / \mathrm{I}$ TDZ and $0.5 \mathrm{mg} / \mathrm{l}$ NAA 3 weeks after culture. More 
shoots are visible. B. Same as in fig. 2A 4 weeks after culture. The shoots elongated further. C. Several elongated well developed shoots originated from callus $45 \mathrm{~d}$ after culture on MS medium supplemented with $2.0 \mathrm{mg} / \mathrm{I} \mathrm{TDZ}$ and $0.5 \mathrm{mg} / \mathrm{I} \mathrm{NAA}$. D. Rooting of shoots on $1 / 2 \mathrm{MS}$ medium supplemented with $3.0 \mathrm{mg} / \mathrm{l}$ IBA 45d after culture. Several roots were emerged from the cut end of the shoot. E. Transplanted plantlets one month after transfer to soil. 